\title{
Agency Problem and the Role of Audit Committee: Implications for Corporate Sector in Bangladesh
}

\author{
Muhammad Zahirul Islam \\ Senior Lecturer, Department of Business Administration, East West University \\ 43 Mohakhali C/A, Dhaka, Bangladesh \\ Tel : 88-017-1665-3964Ｅ-mail: zahir046@ewubd.edu \\ Mohammad Nazrul Islam, ACA, ACMA \\ Assistant Manager, Audit and Advisory Services \\ Rahman Rahman Huq-Chartered Accountants, Dhaka, Bangladesh \\ Tel: 88-017-1634-2488Ｅ-mail: kpmg-rrh@citech-bd.com, nislam@kpmg.com \\ Sumon Bhattacharjee (Corresponding Author) \\ Lecturer, Department of Business Administration, East West University \\ 43 Mohakhali C/A, Dhaka, Bangladesh
}

Tel : 88-017-1285-9617 E-mail: sumon@ewubd.edu, sb_ctg@yahoo.com

A. K. M. Zahirul Islam

Senior Lecturer, Prime University, 2A/1 North East of Darussalam Road

Mirpur-1, Dhaka-1216, Bangladesh

Tel: 88-015-5432-4721Ｅ-mail: Zahictg06@gmail.com

\begin{abstract}
This paper is an attempt to identify various agency relationships that may exist in the economic \& business life $\&$ the related problems that may arise due to such relationships. Corporate governance is a burning issue now a day. We have witnessed a paradigm shift in the corporate governance practices in different countries where audit committee has been addressed and accepted as a striking force. Likely, audit committees in the corporate sector in Bangladesh have a formidable challenge of effectively overseeing the company's financial reporting process in a dramatically changed but improperly regulated or unregulated corporate governance environment. It is also an effort to make a relationship between mitigating the agency problem and the role of audit committee in this respect. .
\end{abstract}

Keywords: Agency Problem, Audit Committee, Information Asymmetry, Corporate Governance

\section{Introduction}

One of the key features of modern corporations is the separation of ownership and control (Berle and Means 1932).Large scale businesses, which were developed during the period of industrial revolution, brought significant changes in financing, ownership and management patterns. Innovation in technologies created necessity of huge investment in the industrial unit. Ownership structure was extended to incorporate Joint Stock type of organization where people from different sections of the society came up to provide necessary fund (Khan et al, 2004:131).Corporate governance systems are developed, in part, to help reduce agency problems. Such systems involve the development of monitoring mechanisms and evaluation procedures to help control an organization's agents and ensure that they behave in the best interests of shareholders.

Comprehensive regulatory changes brought on by recent corporate governance reforms have a broadly redefined and re-emphasized the roles and responsibilities of all the participants in a public company's financial reporting process. Most notably, these reforms have intensified scrutiny of corporate audit committees, whose role as protectors of investors' interests now attracts substantially higher visibility and expectations. The audit committee acts as an intermediary between the firm's managers and the external auditor when there are disputes over accounting matters and it also monitors the firm's financial reporting system and internal controls. The audit committee is commonly viewed as a monitoring mechanism that can make a significant contribution within a good corporate governance framework. However, investors may be expecting too much from audit committees if the underlying accounting and auditing standards are inadequate (Wolnizer 1995). The committee's duties include recommendation and appointment of external auditors, reviewing the company's financial statements, 
taking actions on items and concerns raised by the auditors, mediating between the auditor and management, and advising on any significant findings of external and internal audit investigations (Baruch 1980; Klein 2002). Present notion, practice and implication of audit committees in the corporate sector are not homogeneous over the world. In some countries audit committees are mandated by law (e.g., Canada, Singapore, Thailand), mandated by regulators (e.g., Bangladesh, Malaysia, the U.S), or are strongly encouraged by codes of Best Practice (e.g., the U.K.). In many countries, audit committees are not required although firms can introduce them on a voluntary basis.

Corporate governance practices in Bangladesh are quite absent in most companies and organizations. In fact, Bangladesh has lagged behind its neighbors and the global economy in corporate governance (Gillibrand, 2004). One reason for this absence of Corporate Governance is that most of the companies are family oriented. Moreover, motivation to disclose information and improve governance practices by companies is felt negatively. There is neither any value judgment nor any consequences for corporate governance practices. In Bangladesh, corporate sector is at cross roads as far as legal structure and internal management, control and administration of corporations is concerned. The current system in Bangladesh does not provide sufficient legal, institutional and economic motivation for stakeholders to encourage and enforce corporate governance practices; hence failure in most of the constituents of corporate governance witness in Bangladesh. Considering current corporate governance practices in Bangladesh, Audit Committee can play an important role.

\section{Objectives}

The primary objective of this study is to show the role of audit committee for mitigating the agency cost. One of the motivations for this paper is to articulate the overall concepts of audit committee and its role in the corporate sector. Agency problem is the common phenomenon in the corporate sector. In this paper, an effort is made to give a simplified idea about agency problem and role of audit committee in this respect.

\section{Methodology}

The study has been conducted mainly on the basis of literature survey and secondary information. Various journals and research papers, conference papers presented in the international conference on corporate governance in Bangladesh, seminar papers, World Bank reports, diagnostic study reports and newspaper articles have been surveyed in making this study. Few Chartered Accountants have been personally consulted with in order to have their thoughts in this issue.

\section{Agency Relationship and Agency costs}

Adam Smith, Professor of Moral Philosophy and later better known for his work in the field of economics commented in the Wealth of Nations in 1776 that

"Being the managers of other people's money.... It cannot be well expected that they should watch over it with the same anxious vigilance (as their own). Negligence and profusion, therefore, must always prevail, more or less, in the management of the affairs of such a company."

If the corporation is to fulfill its potential, the market's invisible hand would need a little guidance. The corporation could indeed be the engine of growth, enterprise, and wealth creation, but human frailty meant this was never certain. Adam Smith saw this from the start. It could not be assumed that those in control of the corporation would necessarily fulfill the grand ambition he saw. Indeed, Smith saw humans as motivated primarily by self-interest. This is the reason of agency problem between agent and principal. And agency theory suggests that, owing to the separation of corporate management and ownership, shareholders require protection because managers may have agendas different from their owners (shareholders), and thus may not always act in the owners' best interests (Fama and Jensen, 1983; Fama, 1980; Jensen and Meckling, 1976). Agency theory is concerned with contractual relationships between two or more persons under which, one or more persons, called the agent (s), to perform some services on behalf of the principal. Both the agent and the principal are assumed to be rational economic persons motivated solely by self-interest. The rights and responsibilities of the parties specified in a mutually agreed-upon contract. The principal delegates decision making responsibility to their agent. (Chowdhury, 2004:12). On the other hand, the agent's decision choices are assumed to affect both parties. Such relationships are pervasive in economic and business life and are elements of the more general problem of contracting between entities in the economy (Bromwich, 1992: 316). For example, in the context of public corporation, there are contractual relationships between the shareholders and the Board of Directors, between board of directors and the executives and between the executives and their subordinates. In the above mentioned relationships, the former can be called the principal and the latter can be called the agent. The main reasons behind the relationship include the following: 
- To utilize the special skills and private information possessed by the agent;

- To relax constraints on the principal's time;

The problem in the agency relationship is that agent and the principal may be at variance with each other. For example:

- The agent is generally assumed to a risk-averter and the principal to be a risk-seeker or risk-averter;

- The agent might have a shorter duration with the organization than the principal.

- The agent's earnings are fixed (in the absence of incentive payments) while the principal is the residual claimant;

- The principal does not directly take part in the management decision-making and control (i.e. ownership is separated from management);

- There is information asymmetry between the agent and the principal; in fact principal is ignorant of many details of the agent's activity.

Due to above differential positions between the agent and the principal, the problems with agency relationships may arise because the parties in the association are assumed, as usual in economics, to seek to maximize their own best interests subject to the constraints imposed by the agency structure (Bromwich, 1992:316). Heinrich (2002) identifies agency problems between the following parties:

- between shareholders and top management,

- between controlling and minority shareholders,

- between shareholders and creditors.

The sources of these conflicts are externalities arising from asymmetries of information, differences in attitude towards risk, differences in decision-making rights.

Agency problems between shareholders and management usually arise from a combination of asymmetric information and differences in sensitivity to firm-specific risk. Here the term "sensitivity to firm-specific risk" is used to refer how a decision maker ranks alternative choices differing in their riskiness. The ranking will depend on the decision maker's preferences (i.e. how the decision maker's utility varies with the riskiness of his payoff; these preferences are immutable), but will also depend on how the decision maker's payoff varies with the riskiness of the chosen alternative (Heinrich, 2002: 4)

Conflicts of interest between controlling and minority shareholders may arise because the controlling shareholders, much like controlling managers, can divert part of the firm's resources for their own private benefit at the expense of non-controlling shareholders. In the case of managers, these private benefits may take the form of excessive perquisites, such as corporate jets and lavish headquarter building, or of self-aggrandizing rules without adding value to shareholders, or of delaying necessary restructuring decisions to avoid unpleasant confrontations with employees, unions, politicians and the media. In the case of controlling shareholders, private benefits may take the form of transfer pricing through which profits can be transferred to other firms in which the controlling shareholder has a large cash flow stake or of asset sales at bargain prices to firms owned by the controlling shareholders (Heinrich, 2002:5).

Agency problems arise between creditors and shareholders because creditors don't participate in the high profit firms beyond the contractually agreed debt service, but share in losses in case of insolvency. This asymmetry creates an incentive, once debt has been incurred, for shareholders to prefer the firm undertake more risky investment projects than creditors would like. Bromwich (1992) classified the nature of problems that may arise between the above mentioned parties into four categories:

- Moral hazard with hidden action,

- Moral hazard with hidden information,

- Adverse selection, and

- Signaling models.

Moral hazard with hidden action occurs when the agent can determine to a degree the outcome of his or her actions, and the other party (the principal) can't directly observe the agent's effort, or perfectly infer it from the firm's information systems. With hidden information the agent knows something relevant to the transaction which the principal does not know. This is an example of more general problem of adverse selection where one 
party can't check whether this private information has been utilized in his or her best interests. The problem is therefore for the uninformed party to give incentives to the informed party to use the private information at his or her disposal to benefit the uninformed participant. One accounting-oriented example of adverse selection is where firms of auditors offer services of different quality. The adverse selection or hidden information problem appears if those employing auditors are not to distinguish the quality of the services provided by different audit firms. To overcome the problem, auditors may resort to advertising to market signaling, where they seek to signal their quality by their actions. Such a firm may also seek to make known the formal qualifications of its members if it is generally believed that such qualifications are correlated with the ability to offer high quality services.

The consequences of the agent's shirking can be called as agency costs. Agency costs are the decline in the firm's value due to agent's behavior, which are in divergence with the owners. Jensen and Meckling (1976) argue that realizing the possibility of dysfunctional activity, the principal will seek to limit divergences from his or her interests by incurring different monitoring and bonding costs. Monitoring activities include imposing budget and operating restrictions and constraints on the agent, and linking the compensation with the outcome of monitoring and bonding activities may include items such as accepting contractual limitations on the agent's decision making power and agreeing to have accounts audited by a qualified auditor (Bromwich, 1992:320). But even the incurrence of sufficient monitoring and bonding costs do not necessarily ensure that the agent will maximize the principal's utility. Even after effective monitoring and bonding there will be some residual loss arising from the inability to ensure that the agent acts fully in the principal's interest, given existing monitoring and bonding devices.

The agency costs in any enterprise will depend on the lack of information about the agent's activities, and the costs of monitoring and analyzing the management's performance, the costs of devising a bonus scheme which rewards the agent maximizing the principal's welfare and the costs for determining and enforcing policy rules. Such costs will also depend on the supply of replacement managers. Competitive pressure in the market for managers will limit the freedom of agents to pressure their own interests (Fama, 1980). Similarly, agency costs will also be limited by the opportunities available to sell the enterprise in the market.

\section{Nature of Agency Relationship in Bangladesh}

Like most of the developing countries the national economy in Bangladesh is dominated by large family-owned, state owned and foreign-owned companies that account for a significant proportion of local employment and production (Hossain, 2005:4). Because of such nature of ownership, widely dispersed corporate ownership is not the rule but the exception. As a result, the key potential conflict of interest in developing, transaction and emerging market countries like Bangladesh tends to arise, not between managers and shareholders like the United States and the United Kingdom, but between controlling shareholders on one hand and minority shareholders (domestic and foreign), and other investors, on the other (Oman et al, 2003:11). So, the owner-director is invariably confronted with situations where their interests as major shareholders conflict with that of other shareholders in their companies. The interests of minority shareholders in these situations may be ignored or suppressed (Chowdhury, 2004:136). In Bangladesh, Institutional shareholders including Investment Corporation of Bangladesh (ICB) hold on average 15\% share of Dhaka Stock Exchange listed Companies. Again, in this country, the institutional shareholders have no common forums. The institutional investors deposit their money mainly with government with secured government bonds. They have not invested significantly shares and securities in the corporate sector because of lack of faith in the business community and the stock market. So, the institutional investors in Bangladesh could not take any significant role in corporate governance. In Bangladesh, though ICB has portfolio spreading over 58 companies in 1993, they nominated one director form their own manpower in only 13 of these companies because of shortage in manpower and right expertise which a non executive director should possess. Although the Companies Act 1994, provides that at least two-third of directors shall retire by rotation in the annual general meeting the process of reelection continues for years. Shareholders, both individual and institutional, rarely elect their representatives in the board (Chowdhury, 2004: 139-140). Muzaffar Ahmed (2006) states that in Privatized Commercial Bank (PCB) in Bangladesh the first conflict of interest arises when the directors used to take the services of their own bank take different types of facilities like favoritism and priority in the process of approval, special treatment in the process of approval, favorable treatment in deciding on sectoral ceiling while financing, favoritism in pricing services, favoritism in deciding repayments, favoritism in rescheduling etc. Conflict also arises in proving favorable treatment to the directors of one bank by the directors of other banks against reciprocal treatment and also piloting the projects of friends and 
relatives from the bank. Conflict of interest also arises in case of Boards restriction in providing facilities to the organization competing with the business houses of the directors.

\section{Audit Committee}

An audit committee can be defined as a sub-committee in the governing body that will make arrangement for internal audit and facilitate the completion of external audit. Audit committee tries to enhance the ability of the board to fulfill its legal responsibilities and ensure the credibility and objectivity of the financial reports (Hossain, 2004). Companies establish an audit committee within the board of directors to take active role in overseeing the company's accounting and financial reporting policies and practices (Whittington and Pany, 2001). An audit committee must be composed of majority of independent or non-executive directors who are neither officers or employee of the company (Hossain, 2004). Such a committee should act as a communication link between management, auditors, and the governing body.

Recommendation of forming audit committees of the board of directors (BOD) first came in 1939 from New York Stock Exchange (NYSE). In 1972, the Securities and Exchange Commission (SEC) of USA first recommended the publicly held companies to establish audit committees. In the recent past, major corporate collapses around the globe have shown the weaknesses in corporate governance system even in the economically developed countries. Removing these weaknesses requires appropriate reform and already we have witnessed a paradigm shift in the corporate governance practices in different countries where audit committee has been addressed and accepted as a striking force. Consequentially, expectations of corporate audit committee responsibility and effectiveness has been redefined. Initially, audit committees in board of directors were responsible for the oversight of the financial reporting process, selection of the independent auditor, and receipt of audit results. However, the responsibilities of the audit committees dramatically intensified with the release of two regulatory reforms impacting corporate governance: (1) the 1999 Blue Ribbon Committee's (BRC) Report and Recommendations on Improving the Effectiveness of Corporate Audit Committees (BRC, 1999); and (2) the Corporate and Criminal Fraud Accountability Act of 2002, better known as the Sarbanes-Oxley Act (SOX, 2002) (Vera-Munoz, 2005).

\section{Audit Committee for Agency Problem}

Agency theory posits an inherent moral hazard in principal-agent relations that gives rise to agency costs. For example, agents can adopt accounting procedures and methods that give favorable accounting results and which may maximize their own wealth under compensation and reward incentive schemes. An audit committee is one way to reduce this incentive problem as effective audit committees enhance the quality and credibility of annual audited financial statements; assists the work of the board of directors, which is charged with safeguarding and advancing the interests of shareholders (Alchain and Demsetz 1972; Fama and Jensen 1983).

Prior research has concentrated on issues that are related to the voluntary formation, committee composition, and the benefits of audit committees. Pincus et al. (1989) and Bradbury (1990) document association between various corporate characteristics and the voluntary formation of audit committees in the U.S. and New Zealand, respectively. However, their results are different. For example, Pincus et al. (1989) find associations between ownership patterns and audit committees and between Big 8 auditors and audit committees, but Bradbury (1990) does not. Menon and Williams (1994) examine management ownership, leverage, size, auditor, board composition, and board size as determinants of audit committee formation; auditor and board composition are found to be significant. Deli and Gillan (2000) find that the likelihood of a firm having a completely independent audit committee is negatively associated with firm growth opportunities and managerial ownership, and positively related to firm size and leverage. Wild (1994) finds that the market reacts more favorably to a firm's earnings after an audit committee is established. Klein (1998) contends that the presence of an audit committee has no effect on a range of accounting and market performance measures. DeFond and Jiambalvo (1991) study factors that are associated with public companies which overstated annual earnings for the years 1977-1988, they find that these companies were less likely to have an audit committee. MeMullen (1996) provides evidence that firms with audit committees are associated with fewer shareholder lawsuits alleging fraud, fewer quarterly earnings restatements, fewer SEC enforcement actions, fewer illegal acts, and fewer instances of auditor turnover when there is an auditor-client accounting disagreement. The studies described above use data from the U.S. and New Zealand (Bradbury 1990). Studies have also been carried in other countries. For example, Carson (2002) finds that the presence of audit committees in Australia is more likely if a firm is large and has a Big 5 auditor (Note 1). Collier (1993) finds that directors' shareholding is negatively related to the existence of an audit committee in British firms, and the number of non-executive directors and leverage are positively related to audit 
committees. He finds no association between a firm having an audit committee and having a Big 8 auditor. In following, we discuss the factors for which audit committee may be formed for mitigating the agency cost:

- Firms provide audited financial statements to help reduce the agency costs that arise from the separation of ownership (shareholders) and control (managers). Audit committees can enhance the credibility of the annual reports and thus improve the external reporting function of firms. Hence we expect that companies with high agency costs resulting from the separation of ownership and control will form audit committees to add credibility to the financial statements. These agency costs will be greater for firms with widely dispersed ownership. Consequently, the greater the proportion of outside dispersed shareholders, the more likely it is that the firm will form an audit committee to reduce agency costs. Furthermore, the greater the proportion of dispersed share ownership the more pressure these owners can exert on the firm to introduce an audit committee.

- Outside blockholders owns a substantial number of shares in the firm but they are not represented on the board of directors and are not related to the major shareholder or the directors. Outside blockholders have incentives to closely monitor the firm and they will rely heavily on the published financial statements for information. Because the financial statements are produced by insiders they may lack credibility in the eyes of the blockholders and so the blockholders will put pressure on the firm to set up an audit committee. This pressure will increase with the proportion of shares owned by the outside blockholders. Hence we predict a positive relation between the proportion of shares owned by outside block shareholders and audit committee formation.

- Outside non-executive directors possess two characteristics that enable them to fulfill their monitoring functions. One is the expertise they bring to the position and the other is their independence. Maintaining expertise and independence is important if outside non-executive directors intend to retain or enhance their reputations in the external labor market (Fama and Jensen 1983). Outside directors can increase the quality of monitoring as they are independent representatives of the shareholders' interests (and especially the minority or dispersed shareholders). However, information asymmetries can arise between inside and outside directors. Outside directors may not be very familiar with the company's activities as they can only obtain as much information as the management chooses to give them. Over time, the legal environment has changed and the personal liabilities of the outside directors have increased. They are now required to play a more active role in the company's affairs. We argue that the increased litigation risk faced by outside directors in recent years makes them more likely to insist on the formation of an audit committee. An audit committee gives greater assurance that the financial information is correct and that auditor-management disputes have been satisfactorily resolved.

- DeAngelo (1981) suggests that the Big 8 CPA firms supply a higher level of audit quality than do smaller CPA firms because the Big 8 possess technological advantages that lead to the detection of more material errors in client financial statements. Furthermore, Big 8 auditors are viewed as being more independent as they have greater reputation at stake. Francis and Wilson (1988) also argue that Big 8 auditors provide a higher quality audit than do non-Big 8 auditors. These and other studies imply that there is less information asymmetry for firms that use the services of a Big 8 auditor. The less the information asymmetry, the smaller the demand for enhanced monitoring, and the less likely it is that an audit committee will be formed. Thus the presence of an audit committee can be a substitute mechanism for a Big 5 auditor. One concern investors may have with a non-Big 5 auditor is that they may be less independent and this will reduce the creditability of the financial statements. An audit committee can help increase the independence of a non-Big 5 auditor as it may prevent a firm's managers from threatening to remove the auditor because of disagreements on the financial statements.

- Smith and Warner (1979) and Chow (1982) argue that debt-holder-manager conflicts of interest lead to agency costs of debt. Here, the managers may take actions to divert resources away from the debt-holders (for example, take on high risk projects). To prevent wealth transfers from debt-holders, audit committee can play an important role.

So, audit committee can play a very important role for mitigating agency problem. It can also replace many deficiencies of a particular company which are the causes of agency problem. Deficiency may be lack of independence of external auditor, lack of efficiency of internal control systems etc.

\section{Present Scenario of Corporate Sectors in Bangladesh and Audit Committee}

As the global markets have re-evaluated corporate governance practices in developed countries, the awareness of and the need for better corporate governance in developing countries has gained momentum. As Bangladesh begins to focus on the development of the private sector, strong corporate governance is a key part of increasing economic efficiency and efficiently utilizing domestic investment to achieve greater economic development. Good corporate governance practices will help develop and stimulate better business management, strategic management, and risk management. In the long-term, this will make Bangladeshi business more competitive. 
One key element in improving economic efficiency is corporate governance, which involves a set of relationships between a company's management, its board, its shareholders and other stakeholders. Corporate governance also provides the structure through which the objectives of the company are set, and the means of attaining those objectives and monitoring performance are determined. Good corporate governance... should facilitate effective monitoring; thereby encouraging firms to use resources more efficiently. (Note 2)

But corporate governance environment in Bangladesh has so many weaknesses. As we have mentioned that family dominated business creates huge amount of agency cost, ultimate results of this agency cost is lacking of good environment in corporate sector. Different government institution also faces so many problems for eliminating these types of problem. Following are the main weaknesses of corporate sector in Bangladesh:

Poor Bankruptcy Laws: Bankruptcy laws and processes are not strong in terms of enforcement in Bangladesh. No country can have good corporate governance standards with poor bankruptcy laws and processes. Besides, inefficient foreclosures and securitization processes have compounded the problems in Bangladesh (Hossain, 2005).

No Push from the International Investor Community: Most companies in Bangladesh do not think that they can attract foreign investment. So there is no push from the international investor community for better corporate governance. Bangladeshi company is rarely listed with any foreign stock exchange. Lately, the clearance has been given by the capital market watchdog- the Securities and Exchange Commission (SFC)- to a Bangladeshi pharmaceutical company for listing with the London Stock Exchange (Hossain, 2005). And already the shares of Beximco Pharmaceutical Company are being traded in the London Stock Exchange.

Discrepancy between IAS Requirement and Actual Practice: The SEC rule requires listed companies to follow IASs for its statutory audit under ISAs as adopted by the Institute of Chartered Accountants of Bangladesh (ICAB) as BASs and BSAs respectively. In many cases, the IAS has been adopted in its original form and subsequent amendments have not been incorporated in the BAS. This creates significant difference between IAS and BAS in material aspects. Moreover, no organization in Bangladesh (including the ICAB) issues implementation guidelines on either the BAS or the BSA. Without guidelines, these standards are applied inconsistently. The lack of detailed knowledge about IAS and the absence of implementation guidelines often give rise to misunderstanding, creating a gap between IAS requirements and actual practices (World Bank, 2003). But this requirement does not appear to have the force of mother law, i.e., the Companies Act does not require compliance with BAS.

Inconsistency between Companies Act, BAS and SEC Requirements: The companies Act, 1994 provides, among others, provisions regarding preparation and publication of financial statements, disclosures and auditing. However, in many cases, the Act lacks clarity with regard to statutory requirements on disclosures in the financial statements of listed companies. Moreover some accounting requirements mentioned in the Act are incompatible with International Accounting Standards (IAS) which are required by the SEC. For example, contrary to IAS, the Companies Act requires capitalization of gains and losses arising from changes in foreign exchange rates under all circumstances. Another inconsistency is that the Companies Act does not requires a consolidated balance sheet for a holding company but its required under the IAS. Inconsistencies between IAS and the Companies Act need to be eliminated (World Bank, 2003).

Compliance Gap: In general, actual accounting and disclosure practices in Bangladesh fall far short of the IAS requirements. Some examples are:

$>$ It is common practice not to comply with IAS requirements on consolidation.

Most companies do not follow segment reporting requirement. In a study by World Bank, it has been found that few companies reported segment sales and only one company disclosed segment assets and liabilities.

Limited or No Disclosure regarding Related Party Transactions: Related party transactions are not disclosed properly in the financial statements. It is an impediment towards achieving good corporate governance in Bangladesh.

Weak Regulatory System: Weak regulatory system and board interference with the management retards the improvement of corporate governance in the country (The Daily Star, August 1, 2005). The main problem with regard to the regulatory environment is implementation of the current laws and statutes. It is very difficult and expensive to exercise minority shareholder rights under section 233 of the companies Act. It is also difficult to establish directors are at fault (BEI, 2003).

Capital Market Role: Capital market facilitates good governance through information production and monitoring (Tadesse, 2004). The capital market of Bangladesh consists of two stock exchanges: Dhaka Stock Exchange 
(DSE) and Chittagong Stock Exchange (CSE). Bangladesh does not have depth in its equity market. The capital market of Bangladesh is still a weak link in the movement towards strengthening corporate governance. The overall performance measures of its stock market show low trading volume, intermittent bumps, not many new offerings and unsteady valuations more on the declining side than otherwise (Hossain, 2005). The stock market scandal in 1996 has seriously eroded investor confidence in the stock market (BEI, 2003). One vital aspects is that capital market in Bangladesh do not react significantly to corporate performance in terms of higher stock valuation for accurate disclosure and poor stock price for failure of accurate and full disclosure. There is little incentive in becoming a public company and listing on the stock exchange in Bangladesh. Companies with good reputations can get bank financing relatively easily than through share issue. Moreover, there are very few bonds, fixed income or debt instruments in the capital market. This means there are no pressure groups for enforcing corporate governance principles (BEI, 2003). The state-owned investment company-Investment Corporation of Bangladesh (ICB)- has not, until recently, been required to publish the net asset value of its mutual funds or submit performance reports to the SEC as private mutual funds must do by law.

General Meeting Scenario: General meetings of a company, in particular the Annual General Meeting (AGM) are the primary for where shareholders can raise their concerns and make their influence felt over the management towards attaining good governance. Although a good number of provisions in the Act provided sufficient leverage to allow shareholders a voice in companies, most companies in Bangladesh, are closely held. Small groups of shareholders own or control the majority of shares, and by using that majority, control the decision making processes of the companies (BEI, 20003). Default in holding annual general meetings in time also hampers good corporate governance practice.

Board of Directors: The Companies Act, 1994 provides for many stringent rules in respect of any negligence, default, breach of duty or trust on the part of director, manager or officer of a company. But experience would appear to show that these are more honored in the breach than observance. In an overwhelming majority of the non-bank listed companies, the board is heavily dominated by sponsor shareholders who generally belong to a single family. The boards are actively involved in management. Most independent directors represent current or former government officials or bureaucrats. They are appointed directors to assist company in getting licenses or as payback for previous favors. In the context of Bangladesh, independent directors do not act as an advocate for minority shareholders or as a source of innovative ideas (BEI, 2003).

Lack of Shareholder Activism: Shareholder rights are today recognized in countries across the globe as relevant to efforts for improving and strengthening corporate governance. The average non-controlling shareholder does not possess significant level of education, understanding and sophistication required to exert pressure on a company to change behavior. The number of shareholders with sufficient knowledge and skills to understand company ope5rations and to hold management and the board of directors accountable is very low. Moreover, general shareholders do not pay attention on issues of performance, business strategy, future business plans, disclosures and processes that could give them a greater voice in the policy decisions of a company. In fact, there is very little awareness about shareholders' rights and responsibilities. Shareholders' activism is still an illusion in Bangladesh (Hossain, 2005).

No Market for Corporate Control: A market for corporate control plays an important monitoring function in corporate governance, as poorly managed companies will become takeover targets (Deakin and Slinger 1997 in Morrison, 2004). In Bangladesh, there seems to have no market for corporate control.

Weak Pressure Groups: Shareholders, investor associations, institutional investors and the financial press can play significant role in ensuring better corporate governance. Each of these potential pressure groups is weak in Bangladesh. The numbers of journalists who possess knowledge on financial reporting are limited and there are lacks of investigative reports. Similarly public shareholders are not organized under a common platform (such as shareholder associations) to demand better corporate governance. Unlike institutional investors in most capital markets across the globe, the few state-owned enterprises (SOEs) lack performance spirit and motivation to force companies to improve corporate governance as well as performance.

Lack of Auditor Independence: Auditors in Bangladesh are not considered independent or sufficiently qualified to attest to the validity of the financial statements of corporate entities (BEI, 2003).

Poor Audit Report: Audited financial reports are rarely reliable and free from material misstatements. Despite irregularities (in respect of non compliance with the applicable IASs) in the audit report, the auditors issue unqualified audit report on the financial statements (World Bank, 2003).

So far major problems/hindrances in the way of having good corporate governance in Bangladesh have been discussed. These problems are not unique in Bangladesh. Other countries also suffer from some of these 
hindrances. In the recent past, major corporate collapses around the globe have shown the weaknesses in corporate governance. Removing these weaknesses requires appropriate reform and implementation thereof.

In Bangladesh, audit committees in the corporate sector have a formidable challenge of effectively overseeing the company's financial reporting process in a dramatically changed but improperly regulated or unregulated corporate governance environment. Like other countries in the world, audit committee is of utmost importance in Bangladesh as well for independent measurement of management performance. In recent past, the Securities and Exchange Commission (SEC) issued several conditions relating to audit committee through SEC Notification No. SEC/CMRRCD/2006-158/Ad,om/02-08, Dated the $20^{\text {th }}$ February, 2006. In this notification, several conditions on constitution of audit committee, chairman of the audit committee and reporting of the audit committee (to the board of directors, to the authorities and to the shareholders and general investors) have been issued. A brief description of SEC notification is given below:

- The audit committee should be composed of at least 3 (three) members. (Condition 3.1 (i)).

- At least one of the members of the audit committee will be independent director (Condition 3.1 (ii)).

- Nothing is specified regarding the term of office.

- Nothing is specified regarding the existence of audit committee secretary or the appropriate person for the post.

- The Board of Directors should select 1 (one) member of the Audit Committee to be Chairman of the Audit Committee (Condition 3.2(i)).

- No clear statement of the duties of the audit committee is provided. Emphasis is given on the written requirement of the duties.

- No condition is imposed regarding the frequency of audit committee meeting.

- The Audit Committee should immediately report to the Board of Directors on different findings like conflicts of interests, suspected or presumed fraud or irregularity of material defect in the internal control system, suspected infringement of laws, including securities related laws, rules and regulations; and any other matter which should be disclosed immediately (Condition 3.3.1(ii)).

- Report on activities carried out by the Audit Committee, including any report made to the Board of Directors under condition 3.3.1 (ii) above during the year, should be signed by the Chairman of the Audit Committee and disclosed in the annual report of the issuer company (Condition 3.4).

- Voluntary compliance on part of all the listed companies in Bangladesh as the conditions are issued on 'comply or explain' basis.

By analyzing the legal framework of audit committee in Bangladesh, it has been found that nothing is conclusive i.e. all aspects of audit committee have not been covered in this legal papers. For example, with respect to audit committee meeting, SEC notification has not provided any condition. Again, 'reporting of the audit committee' part is much clearer where audit committee is made responsible for reporting to not only to the board of directors on a regular basis but also to the shareholders and investors in the annual report and to the Securities and Exchange Commission (SEC) in case of unreasonable ignorance on part of the board of directors regarding anything which has material impact on the financial condition and results of operation by the audit committee (SEC Notification 2006, Condition 3.3). Still, ample areas and issues are there to thwart or to make the audit committee function too vulnerable to work as a corporate watchdog or corporate whistleblower.

\section{Concluding discussions and Policy Recommendations}

Agency problem is and will be there as long as there is the existence of corporate type of organization. We have already observed that not only agency problem but also the failure of different instrument of corporate governance creates so many problems. An independent audit committee is one of the important mechanisms for minimizing these types of problems. It is expected to satisfy the need of both internal and external users of financial statements. Similarly, the formation of an audit committee has a lot of value to different types of users which ensure the credibility of the financial information. On the basis of our observation in the current corporate governance environment and formation of audit committee, we have following recommendations regarding formation of audit committee and improvement of corporate sector in Bangladesh:

- An independent audit committee is one of the important mechanisms in this respect. It is expected to satisfy the need of both internal and external users of financial statements. Prior studies have documented the importance of the independence of audit committee members for maintaining the integrity and quality of the corporate financial reporting process (e.g., Klein, 2002; Carcello and Neal, 2003, 2000; Dechow et al., 1996; Defond and Jiambalvo, 
1991) Committee members should understand the difference between the oversight function of the committee and the decision-making function of management, and must be willing to challenge management when necessary (BRC, 1999).

- We have already mentioned that only single independent member in the audit committee among total members of 3 or more. Quite rationally, the independent director is not in a position to apply his independence to notify and stop any vested interest of the directors or management. Although most financial institutions have independent directors (following the legal compliance) they rarely or never intervene in the decision making process of the board; where as independent directors in non-financial public limited organization play nominal role (Haque, 2007). In USA, SOX requires that audit committees be composed of all independent directors for firms traded on an organized stock exchange (e.g., NYSE, AMEX) or a recognized dealer quotation system (e.g., NASDAQ). Under the existing situation and practices in Bangladesh, we express our favor for having at least two third independent members in the audit committee.

- Audit committee must have a financial expert as member who possesses either professional qualification or experience preparing, auditing, analyzing, or evaluating financial statements; and have an understanding of audit committee functions. In January 2003, the SEC in USA adopted rules requiring companies to disclose in their annual reports whether it has at least one member of audit committee is financial expert or , if one does not exist, why not. Recent studies also examined the association between the financial expertise of audit committee members and corporate financial reporting quality (Farber, 2004; Abbott et al., 2002; McDaniel et al., 2002).

- There should be such provision that, audit committee need to report semiannually or annually to the stipulated regulatory authority regarding any matter which has material impact on the financial condition, results of operation and on future risk and profitability of the business. It should be counter-signed by the CEO and the chairman of the committee. Provision regarding this issue available in current regulations, but it is not mandatory.

- Audit committee should have the scope and authority to provide commentary or interpretation on any unsolved issue on which either the board and management, or the board and minority shareholders are not unanimous.

- The Securities and Exchange Commission (SEC) of Bangladesh need to be strengthened so that it can devise and enforce a code for good corporate governance [adapted from the recommendations made by participants in the 2-day international conference on CG in Bangladesh jointly organized by the Center for Corporate Governance and Finance Studies (CCGFS) of Dhaka University, Dhaka Stock Exchange (DSE), Organization for Economic Corporation and Development (OECD) and the Asia Foundation. Source: The Daily Star, August $1,2005]$.

- The Companies Act has to be amended and updated to have consistency with SEC requirements and the Bank Companies Act.

- Stock exchange (both DSE and CSE) can update their listing criteria to ensure proper function of audit committees in corporate sector.

The formation of an audit committee has a lot of value to different types of users. But one thing is that too much emphasis on one mechanism and ignorance of the other would be unwise. Because, while audit committees have the potential to give a further layer of assurance to creditors and investors, the recent debacles in the world warn us that good corporate governance means more than just establishing committees and systems. Expertise, commitment, and, above all, independence are sorely needed to ensure the effectiveness of audit committees as an integral part of the governance process.

\section{References}

Abbott, L., Y. Park and S. Parker. (2000). 'The effects of audit committee activity and independence on corporate fraud', Managerial Finance 26, 55-67.

Alchian, A. \& Demsetz, H. (1972). Production, information costs and economic organization. American Economic Review, 777-795.

Ahmed, M. (2006). Corporate Governance in Bangladesh Financial Sector. Paper presented in ICMAB Conference 2006: 84-96.

Ahmed, F. (2006). Key not Speech provided in ICMAB Conference 2006 on "Corporate Governance-Bangladesh Perspective".

Abbott, L., Y. Park, and S. Parker. (2000). The effects of audit committee activity and independence on corporate fraud. Managerial Finance, Vol. 26, 55-67. 
Ahmed, U., M. and Mohammad, Y.A. (2005). Corporate Governance: Bangladesh Perspective. The Cost and Management. (November-December) : 18-26.

Bangladesh Enterprise Institute (BEI). (2003). A Comparative Analysis of Corporate Governance in South Asia: Charting a Roadmap for Bangladesh BEI, Dhaka, Bangladesh.

Baruch, H. (1980). The audit committee: A guide for directors. Harvard Business Review 58, 174-186.

Bhuiyan, H.M., \& Biswas, P.K. (2006). Agency problem and the role of Corporate Governance. The Bangladesh Accountant (July-September):109-117.

Berle, A.A., \& Means, G.C. (1932). The Modern Corporation and Private Property. New York: Macmillan.

Bromwich, M. (1992). Financial Reporting, Information and Capital Markets. Pitman Publishing, London.

Cadbury Committee (1992). Report of the Committee on the Financial Aspects of Corporate Governance. Gee Publishing, London.

Carcello, J., and T. Neal. (2003). "Audit committee characteristics and auditor dismissals following "new" going-concern reports', The Accounting Review 78(1), 95-117.

Carcello, J., and T. Neal. (2000). 'Audit committee composition and auditor reporting', The Accounting Review 75(4), 453-467.

Carson, E. (2002). Factors associated with the development of board sub-committees. Corporate Governance: An International Review 10, 4-18.

Chow, C.W. (1982). The demand for external auditing: Size, debt and ownership influences. Accounting Review 57, 272-291.

Collier, P.A., \& Gregory, A. (1999). Audit committee activity and agency costs. Journal of Accounting and Public Policy 18, 311-332.

Chowdhury, D. (2004). Incentives, Control and Development: Governance in Private and Public Sector with Special Reference to Bangladesh. Dhaka Viswavidyalay Prakashana Samstha, Dhaka.

DeAngelo, L.E. (1981). Auditor size and audit quality. Journal of Accounting and Economics 3, 183-199.

Dechow, P., R. Gloan and A. Sweeney. (1996). 'Causes and consequences of earnings manipulation: An analysis of firms subject to enforcement actions by the SEC', Contemporary Accounting Research 13(1), 1-36.

DeFond, M.L. \& Jiambalvo, J. (1991). Incidence and circumstances of accounting errors. Accounting Review 66, 643-655.

Degeorge, F., \& Keegan, M. (1997). Audit Committees: A Study in European Corporate Governance, London: Price Waterhouse.

Deli, D.N., \& Gillan, S.L. (2000). On the demand for independent and active audit committees. Journal of Corporate Finance 6, 427-445.

Fama, E.(1980). 'Agency problems and the theory of the firm', Journal of Political Economy 2, 288-307.

Fama, E. F., \& Jensen, M.C. (1983), Separation of ownership and control. Journal of Law and Economics 26(2), 301-326.

Francis, J. \& Wilson, E. (1988). Auditor changes: A test of theories relating to agency costs and auditor differentiation. Accounting Review 58, 663-682.

Gillibrand, M. (2004), "Corporate management essential for industrialization” The Bangladesh Ovserver, April 17, 2004.

Gregory, Holy J. (2000). International Comparison of Corporate Governance Guidelines and Code of Best Practices. New York, Weil. Gotshal \& Manges LLP:i.

Haque, A.K.E., Jalil, B., \& Naz, F. (2007). State of corporate Governance in Bangladesh. Analysis of Public Limited Companies- Financial, Non-Financial Institutions and State Owned Enterprises. Working Paper Series No 2. East West University Center For Research And Training, 24.

Heinrich, P. Ralph. (2002). Complementarities in Corporate Governance. Springer, Berlin.

Hossain, I. (2005). Corporate and Political Governance: Relationship Based Versus Rules Based. The Bangladesh Accountant (October-December) 49(22): 4-6. 
Jensen, M.C., \& Meckling W.H. (1976). Theory of the firm: managerial behavior, agency costs and ownership structure. Journal of Financial Economics 3, 305-360.

Klein, A. (2002). Economic determinants of audit committee independence. Accounting Review 77, 435-452.

Khan, R.A, Siddique, J., and Hossain, M.D. (2004). Reporting on Corporate Governance as a Voluntary Disclosure: A Study on the Annual Reports of BEXIMCO Group. Dhaka University Journal of Business Studies (June) XXV (1):135-145.

McDaniel, L., R. Martin, and L. Maines. (2002). 'Evaluating financial reporting quality: The effects of financial expertise vs. financial literacy', The Accounting Review (Supplement), 139-167.

McMullen, D.A.(1996). Audit committee performance: An investigative of the consequences associated with audit committees. Auditing: A Journal of Practice and Theory 15, 87-103.

Menon, K., \& Williams, J.D. (1994). The use of audit committees for monitoring. Journal of Accounting and Public Policy 13, 121-139.

Morrison, J. (2004). "Legislating for Good Corporate Governance: Do We Expect Too Much?" The Journal of Corporate Citizenship, Autumn (Iss.15): 121-133.

Pincus, K., Rusbarsky, M., \& Wong, J.W. (1989). Voluntary formation of corporate audit committees among NASDAQ firms. Journal of Accounting and Public Policy 8, 239-265.

Smith, C.W., \& Warner, J.B. (1979). On financial contracting: An analysis of bond covenants. Journal of Financial Economics 7, 117-161.

Smith, C.W., \& Watts, R.L. (1992). The investment opportunity set and corporate financing, dividend, and compensation policies. Journal of Financial Economics 32, 263-292.

Tadesse, S. (2004). "The Allocation and Monitoring Role of Capital Markets: Theory and International Evidence," Journal of Financial and Quantitative Analysis (Seattle), December, 39(4).

Wild, J.J.(1994). The audit committee and earnings quality. Journal of Accounting, Auditing and Finance9, 247-276.

Wolnizer, P.W. (1995). Are audit committees red herrings? Abacus 31(1), 45-66.

World Bank. (2003). "Report on the observance of standards and codes (ROSC) Bangladesh Accounting and Auditing," World Bank Report, prepared by Rahman and Zannath (see www.worldbank.org/ifa/rosc aa bgd.pdf dt. 12/8/05).

\section{Notes}

Note 1: The Big 8 successively became the Big 6, the Big 5, and, now, the Big 4.

Note 2: OECD Principles of Corporate Governance, p. 12 